\title{
OPTIMASI MODEL PROBLEM BASED LEARNING BERBANTUAN MULTIMEDIA UNTUK MENINGKATKAN KETERAMPILAN KERJA TIM DI SEKOLAH DASAR
}

\author{
Agung Rimba Kurniawan ${ }^{1}$, Silvina Noviyanti ${ }^{2}$, Arsil $^{3}$ \\ ${ }^{1,2,3)}$ PGSD FKIP Universitas Jambi \\ E-mail: ${ }^{1}$ agung.rimba@unja.ac.id \\ ${ }^{2)}$ silvinanoviyanti@unja.ac.id \\ ${ }^{3)}$ arsil.fkip@unja.ac.id
}

\begin{abstract}
Abstrak: Tujuan penelitian ini mengetahui bentuk rencana pelaksanaan pembelajaran yang disusun menggunakan model problem based learning berbantuan multimedia dan mendeskripsikan penerapan model problem based learning berbantuan multimedia dalam meningkatkan keterampilan kerja tim pada kegiatan pemecahan masalah siswa sekolah dasar. Jenis penelitianini adalah penelitian tindakan kelas. Tempat penelitian SDN 64/I Muara Bulian, subjek penelitian yaitu siswa kelas V. Prosedur penelitian: 1) perencanaan 2) pelaksanaan, 3) pengamatan dan 4) refleksi. Teknik Pengumpulan data: Observasi dan Dokumentasi. Penelitian telah dilakukan sebanyak 2 siklus.Hasil penelitian yaitu rencana pelaksanaan pembelajaran disusun bersama tim peneliti dan guru kelas yang mengikuti standar pada kurikulum 2013, Penerapan model problem based learning berbatuan multimedia dalam meningkatkan keterampilan kerja tim, terlihat dalam kegiatan pemecahan masalah di dalam kelompok/tim pada proses pembelajaran IPA di kelas V. Setiap tim diberikan sebuah permasalahan melalui video pembelajaran dan mendiskusikannya bersama anggota. Selanjutnya tim mempresentasikan hasil dari diskusi /kerja tim yang telah dilakukan. Hasil pengamatan pada siklus I di peroleh data $70.23 \%$ siswa telahberkontribusi dalam kegiatan kerja tim, dan pada siklus II juga semakin meningkat menjadi $90.23 \%$ siswa.
\end{abstract}

\section{Kata kunci: Problem Based Learning, Keterampilan Kerja Tim}

\begin{abstract}
The purpose of this study is to know the form of learning implementation plan that is prepared using multimedia assisted problem based learning models and describe the application of multimedia assisted problem based learning models in improving team work skills in problem solving activities of elementary school students. This type of research is classroom action research. The place of research is SDN 64 / I Muara Bulian, the subject of research is class V students. Research procedures: 1) planning 2) implementation, 3) observations and 4) reflection. Data collection techniques: Observation and Documentation. The study was conducted in 2 cycles. The results of the study are that the implementation of learning plans are arranged together with the research team and class teachers who follow the standards in the 2013 curriculum. The application of multimedia-based problem based learning models in improving team work skills is seen in problem solving activities in groups / teams in the science learning process in class V Each team is given a problem through learning videos and discussing them with members. Next the team presents the results of the discussion / team work that has been done. The results of the observations in the first cycle were obtained by $70.23 \%$ of students who had contributed to the team work activities, and in the second cycle it also increased to $90.23 \%$ of students.
\end{abstract}

Keywords: Problem Based Learning, Team Work Skills

Submitted on: 2019-05-23

Accepted on: 2019-08-26 
PENDAHULUAN

Sistem belajar melalui kerja tim sangat populer di sekolah dasar, dan sering digunakan dalam proses pembelajaran. Kenyataannya, sistem belajar atau kerja tim yang sudah berjalan di tingkat pendidikan dasar belum sesuai harapan.

Berdasarkan hasil studi pendahuluan peneliti memperoleh informasi melalui wawancara di kelas IV SD yang menyatakan bahwa di kelasnya terdapat berbagai macam masalah seperti keaktifan belajar yang kurang, siswa jarang yang mau bertanya, berpendapat saat diskusi, dan juga belum kompak dalam memecahkan masalah di dalam belajar kelompok, siswa belum terbiasa melakukan pemecahan masalah melalui kerja tim. Informasi / ilmu pengetahuan terbiasa di dapatkan melalui penjelasan guru.

Melihat keluhan wali kelas IV SD tersebut, kemudian peneliti melakukan observasi di kelas tersebut. Ternyata, memang benar apa yang disampaikan wali kelas IV bahwa dalam proses pembelajaran kelompok, keterampilan kerja tim siswa memang rendah.

Hasil observasi, ada tim yang kurang mendengarkan dengan baik ketika teman berpendapat, hanya 1 tim yang berdiskusi memecahkan masalah dengan cara setiap anggota tim harus memberikan pertanyaannya masing-masing, tim tidak fokus mengerjakan tugas pemecahan masalah bersama tim. Anggota tim hanya asik sendiri dengan kegiatannya tanpa mempedulikan tugas yang diberikan guru, setiap tim tidak ada anggota memberikan gagasan/ide apabila menyelesaikan tugas kelompok, saat berdiskusi dengan tim, hanya beberapa anggota saja yang mengerjakan tugas kelompok selebihnya hanya melihat saja, setiap tim tidak ada yang melakukan diskusi pemecahan masalah kemudian mengambil keputusan secara bersama atas dasar pertimbangan anggota tim, yang terlihat hanya ketua kelompok yang mengambil keputusan dalam kelompok tanpa berdiskusi dengan anggota kelompoknya, tim tidak saling memberikan dukungan yang sedang menyampaikan hasil diskusi, anggota tim hanya diam, apabila diberi pertanyaan dari tim lain kepada anggota tim tidak bisa menjawab, hanya ketua tim saja yang menjawab pertanyaan.

Akar penyebab masalah rendahnya kerja tim siswa yaitu siswa belum terbiasa melakukan pemecahan masalah dalam kerja tim, pembelajaran yang disajikan guru kurang menarik, tidak memanfaatkan multimedia, proses pembelajaran yang kurang terstruktur atau belum direncanakan dengan baik misalnya menggunakan model pembelajaran. 


\section{ELSE (Elementary School Education Juurnal) \\ Volume 3 Nomor 2 Agustus 2019 \\ P-ISSN: 2581-1800 E-ISSN: 2597-4122 \\ Email:else@um-surabaya.ac.id}

Masalah rendahnya Keterampilan kerja tim siswa tentu harus segera dilakukan tindakan, agar siswa menjadi terampil dalam memecahkan masalah bersama tim dan dapat ditingkatkan sesuai yang diharapkan. Melihat akar penyebab masalah di atas, peneliti dan wali kelas mengambil tindakan menerapkan model Problem Based Learning berbantuan multimedia.

Penelitian ini memberikan konstribusi meningkatkan mutu Pendidikan Sekolah Dasar di Indonesia khususnya SDN 64/I Muara Bulian seperti :

- Sebagai Inovasi dalam pembelajaran di sekolah dasar yang sejalan dengan tantangan di era revolusi industri 4.0 .

- Penerapan IPTEK dalam proses pembelajaran dengan memanfaatkan multimedia.

Pada era revolusi industri 4.0 dan university 5.0 maka dibutuhkan keterampilan yang memadai.Salah satunya ialah melek teknologi. Melalui penerapan model pembelajaran yang memanfaatkan multimedia, sehingga guru dan siswa di sekolah dasar tidak akan ketinggalan dalam pemanfaatan IPTEK. Melalui penelitian ini dapat mengatasi keterampilan kerja tim dalam memecahkan masalah.

Adapun penelitian terdahulu yaitu dilakukan oleh Kunti Dian Ayu Afiani dan Deni Adi Putra mengenai Peningkatan Kemampuan Berpikir Kreatif Pada Siswa Kelas III SD Melalui Pembelajaran Berbasis Pengajuan Masalah. Hasil dari penelitian ini adanya perubahan kemajuan tingkat berpikir kreatif siswa pada siklus-1 sebesar 48,72\% dan pada siklus-2 sebesar 87,18\%. Hasil tersebut telah menunjukkan bahwa melalui pembelajaran berbasis pengajuan masalah dapat meningkatkan kemampuan berpikir kreatif pada siswa kelas III SD. Dari penelitian terdahulu yang telah dilakukan terdapar persamaan yaitu sama-sama menggunakan atau beracuan model pembelajaran berbasis masalah, jenis penelitian juga sama penelitian tindakan kelas. Namun, yang menjadi perbedaan dengan penelitian yang kami lakukan yaitu pertama, peneliti menggunakan multimedia sebagai pendukung model pembelajaran berbasis masalah dan kedua terletak pada aspek permasalahan. Peneliti mengambil permasalahan keterampilan kerja tim siswa. Sehingga dari uraian tersebut, tentu ada keterbaruan dalam penelitian ini.

Berdasarkan dari penjelasan latar belakang di atas peneliti tertarik untuk melakukan penelitian dengan judul "Optimasi Model PBL (Problem Based Learning) Berbantuan Multimedia Sebagai Solusi Meningkatkan Kerjasama Tim dalam Kegiatan Pemecahan Masalah di Sekolah Dasar". 


\section{METODE PENELITIAN}

\section{Jenis Penelitian}

Penelitian ini menggunakan jenis penelitian tindakan kelas, menggunakan prosedur Kemmis \& Mc. Taggart, (Arikunto, dkk, 2008:16) yaitu: Perencanaan, Pelaksanaan, Pengamatan, Refleksi.

\section{Subjek Penelitian}

Subjek penelitian adalah siswa kelas IV SDN 64/I Muara Bulian. Jumlah siswa di kelas tersebut adalah 28 orang. Objek dalam penelitian ini yaitu variabel yang diteliti dalam rangka memecahkan permasalahan yang telah dirumuskan yaitu keterampilan Kerja Tim dan kegiatan memecahkan permasalahan yang akan ditingkatkan menggunakan model $P B L$ berbantuan Multimedia.

\section{Teknik Pengumpulan Data}

a. Observasi

Pengamatan dilakukan terhadap keterlaksanaan RPP yang dilakukan guru, Observasi terhadap keterampilan kerja tim siswa.

b. Dokumentasi

Dokumentasi berupa Video. Pengambilan video dilakukan untuk memudahkan peneliti menganalisis proses pembelajaran selama penelitian.

\section{Teknik Analisa Data}

a. Observasi Keterlaksanaan RPP

Keterlaksanaan RPP dianalisis secara deskriptif kuantitatif. Penilaian ini meliputi pendahuluan, kegiatan inti, penutup dan pengamatan susasana kelas menggunakan skala Gutman.Penilaian dan pengamatan dilakukan setiap tatap muka.Dalam menganalisis hasil keterlaksaan RPP, peneliti menggunakan persamaan:

$$
\mathbf{P}=\frac{\sum K}{\sum N} \times 100 \%
$$

\section{Ket :}

$\mathrm{P} \quad=$ Skor Tingkat terlaksananya RPP

$\sum \mathrm{K}=$ Total langkah-langkah/indiaktor terlaksana

$\sum \mathrm{N}=$ total indikator/langkah-langkah (Arifin.Z, 2010:272) 


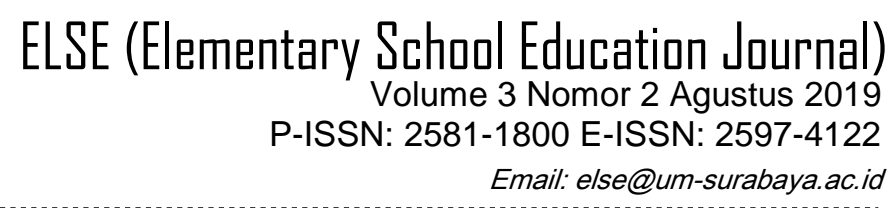

Hasilnya kemudian dinyatakan dalam rentang nilai sebagai berikut.

Tabel 1. Kriteria Keterlaksanaan RPP

\begin{tabular}{cl}
\hline Rentang pengelolaan & \multicolumn{1}{c}{ Kriteria } \\
\hline $\mathbf{0 \%}-\mathbf{2 5 \%}$ & Kurang Terlaksana \\
$\mathbf{2 6 \%}-\mathbf{5 0 \%}$ & Cukup terlaksana \\
$\mathbf{5 1 \%}-\mathbf{7 5 \%}$ & Terlaksana \\
$\mathbf{7 6} \%-\mathbf{1 0 0 \%}$ & Sangat Terlaksana \\
\hline
\end{tabular}

Sumber: Adaptasi dari Kurniawan, AR (2016)

b. Observasi Keterampilan Kerja Tim Siswa

Hasil observasi keterampilan kerja tim siswa akan dianalisis menggunakan cara mendeskripsikan setiap indikator dan menghitung skor menggunakan Rating Scale 1-5 pada setiap indikator melalui analisis video. Kemudian dihitung menggunakan rumus Aries dan Haryono (2012:95).

Keterampilan Kerja Tim $=\frac{\sum \text { skor Tiap Siswa }}{\sum \text { Skor Maksimal }} \times 100 \%$

Tabel 2. Kriteria Keterampilan Kerja Tim Siswa

\begin{tabular}{cl}
\hline Rentang Nilai & \multicolumn{1}{c}{ Kriteria } \\
\hline $\mathbf{7 6 - 1 0 0}$ & Sangat Tinggi \\
$\mathbf{5 1 - 7 5}$ & Tinggi \\
$\mathbf{2 6 - 5 0}$ & Cukup \\
$\mathbf{0 - 2 5}$ & Rndahh \\
\hline
\end{tabular}

Sumber : Adaptasi dari Purwanto (2009:101)

\section{Kriteria Keberhasilan}

Penelitian ini akan dikatakan berhasil jika sudah mengalami peningkatan antara keterampilan kerja tim awal dan kemampuan pemecahan masalah siswa dari kondisi awal dan setelah dilaksanakan pembelajaran beracuan PBLberbantuan multimedia hingga selesainya tindakan. Adapun rincian keberhasilan penelitian yaitu apabila adanya peningkatan di kelas IV SDN 64/I Muara Bulian, yakni mencapai minimal 85\% dari jumlah seluruh siswa.

\section{HASIL DAN PEMBAHASAN}

\section{Hasil Penelitian}

Penelitian tindakan kelas ini dilakukan untuk mengetahui bagaimana bentuk RPP disusun dengan model PBL berbatuan Multimedia dan mengetahui bagaimana penerapan model PBL berbatuan Multimedia dalam meningkatkan keterampilan kerjasama tim dalam kegiatan pemecahan masalah siswa kelas IV SDN 64/I Muara Bulian. Peneliti 
berkolaborasi dengan wali kelas IV SD Negeri 64/I Teratai.Penelitian ini terdiri dari 2 siklus, yang setiap siklus terdiri dari 2 pertemuan.Setiap sikluas terdiri dari 4 tahapan yaitu; (1) Perencanaan, (1) Pelaksanaan, (3) Observasi, dan (4) Refleksi.

Keterlakanaan Rencana Pelakasanan Pembelajaran yang dilakukan oleh guru, berdasarkan hasil pengamatan telah terlaksana dengan baik selama 2 siklus.Hal ini menunjukkan persiapan yang dilakukan memang sanagt matang sesuai dengan perencanaan yang telah ditentukan.

Adapun hasil pengamatan keterampilan kerja tim siswa dapat dilihat pada tabel 5 dan 6 sebagai berikut.

Tabel 3. Hasil Pengamatan Keterampilan Kerja Tim Siswa Siklus I

\begin{tabular}{|c|c|c|c|c|c|c|c|}
\hline \multirow[t]{2}{*}{ No. } & \multirow[t]{2}{*}{ Nama Siswa } & \multicolumn{3}{|c|}{ Indikator } & \multirow{2}{*}{$\begin{array}{c}\text { Jumlah } \\
\text { Skor }\end{array}$} & \multirow[t]{2}{*}{ Persentase } & \multirow[t]{2}{*}{ Kriteria } \\
\hline & & 1 & 2 & 3 & & & \\
\hline 1. & ARTR & 3 & 3 & 3 & 9 & 60 & CUKUP \\
\hline 2. & AA & 3 & 4 & 3 & 10 & 66.6 & BAIK \\
\hline 3. & AAM & 4 & 3 & 4 & 11 & 73.3 & BAIK \\
\hline 4. & AR & 4 & 3 & 5 & 12 & 80 & BAIK \\
\hline 5. & DG & 4 & 3 & 4 & 11 & 73.3 & BAIK \\
\hline 6. & FA & 4 & 3 & 5 & 12 & 80 & BAIK \\
\hline 7. & FINA & 3 & 4 & 5 & 12 & 80 & BAIK \\
\hline 8. & HAB & 3 & 4 & 3 & 10 & 66.6 & BAIK \\
\hline 9. & JP & 3 & 3 & 5 & 11 & 73.3 & BAIK \\
\hline 10. & KH & 4 & 4 & 3 & 11 & 73.3 & BAIK \\
\hline 11. & MO & 3 & 3 & 3 & 9 & 60 & CUKUP \\
\hline 12. & MDA & 2 & 3 & 3 & 8 & 53.3 & CUKUP \\
\hline 13. & MFD & 3 & 3 & 3 & 9 & 60 & CUKUP \\
\hline 14. & $\mathrm{NN}$ & 4 & 3 & 5 & 12 & 80 & BAIK \\
\hline 15. & RH & 4 & 4 & 4 & 12 & 80 & BAIK \\
\hline 16. & RNK & 3 & 3 & 3 & 9 & 60 & CUKUP \\
\hline 17. & RA & 3 & 3 & 4 & 10 & 66.6 & BAIK \\
\hline 18. & RJM & 4 & 5 & 4 & 13 & 86.6 & SANGAT BAIK \\
\hline 19. & RHSA & 3 & 3 & 3 & 9 & 60 & CUKUP \\
\hline 20. & RDA & 3 & 4 & 5 & 12 & 80 & BAIK \\
\hline 21. & SA & 4 & 3 & 3 & 10 & 66.6 & BAIK \\
\hline 22. & SKN & 4 & 3 & 4 & 11 & 73.3 & BAIK \\
\hline 23. & SR & 3 & 4 & 3 & 10 & 66.6 & BAIK \\
\hline 24. & TKJ & 3 & 4 & 4 & 11 & 73.3 & BAIK \\
\hline 25. & UHT & 3 & 3 & 3 & 9 & 60 & CUKUP \\
\hline 26. & VA & 3 & 3 & 3 & 9 & 60 & CUKUP \\
\hline 27. & YKGG & 4 & 3 & 4 & 11 & 73.3 & BAIK \\
\hline 28. & YBP & 3 & 4 & 5 & 12 & 80 & BAIK \\
\hline \multicolumn{2}{|c|}{ Rata-rata/Kriteria } & & & & & 70.23 & BAIK \\
\hline
\end{tabular}


Tabel 4. Hasil Pengamatan Keterampilan Kerja Tim Siswa Siklus I

\begin{tabular}{|c|c|c|c|c|c|c|c|}
\hline \multirow[t]{2}{*}{ No. } & \multirow[t]{2}{*}{ Nama Siswa } & \multicolumn{3}{|c|}{ Indikator } & \multirow{2}{*}{$\begin{array}{c}\text { Jumlah } \\
\text { Skor }\end{array}$} & \multirow[t]{2}{*}{ Persentase } & \multirow[t]{2}{*}{ Kriteria } \\
\hline & & 1 & 2 & 3 & & & \\
\hline 1. & ARTR & 4 & 5 & 4 & 13 & 86.6 & SANGAT BAIK \\
\hline 2. & AA & 4 & 4 & 4 & 12 & 80 & BAIK \\
\hline 3. & AAM & 5 & 5 & 4 & 14 & 93.3 & SANGAT BAIK \\
\hline 4. & AR & 5 & 5 & 5 & 15 & 100 & SANGAT BAIK \\
\hline 5. & DG & 5 & 5 & 4 & 14 & 93.3 & SANGAT BAIK \\
\hline 6. & FA & 5 & 5 & 5 & 15 & 100 & SANGAT BAIK \\
\hline 7. & FINA & 4 & 4 & 5 & 13 & 86.6 & SANGAT BAIK \\
\hline 8. & HAB & 4 & 4 & 5 & 13 & 86.6 & SANGAT BAIK \\
\hline 9. & JP & 4 & 5 & 5 & 14 & 93.3 & SANGAT BAIK \\
\hline 10. & $\mathrm{KH}$ & 5 & 4 & 4 & 13 & 86.6 & SANGAT BAIK \\
\hline 11. & MO & 4 & 5 & 5 & 14 & 93.3 & SANGAT BAIK \\
\hline 12. & MDA & 4 & 3 & 4 & 11 & 73.3 & BAIK \\
\hline 13. & MFD & 5 & 5 & 4 & 14 & 93.3 & SANGAT BAIK \\
\hline 14. & NN & 5 & 5 & 5 & 15 & 100 & SANGAT BAIK \\
\hline 15. & RH & 5 & 4 & 4 & 13 & 86.6 & SANGAT BAIK \\
\hline 16. & RNK & 4 & 5 & 5 & 14 & 93.3 & SANGAT BAIK \\
\hline 17. & RA & 4 & 5 & 4 & 13 & 86.6 & SANGAT BAIK \\
\hline 18. & RJM & 5 & 5 & 5 & 15 & 100 & SANGAT BAIK \\
\hline 19. & RHSA & 4 & 5 & 4 & 13 & 86.6 & SANGAT BAIK \\
\hline 20. & RDA & 4 & 4 & 5 & 13 & 86.6 & SANGAT BAIK \\
\hline 21. & SA & 4 & 4 & 5 & 13 & 86.6 & SANGAT BAIK \\
\hline 22. & SKN & 5 & 4 & 5 & 14 & 93.3 & SANGAT BAIK \\
\hline 23. & SR & 4 & 5 & 4 & 13 & 86.6 & SANGAT BAIK \\
\hline 24. & TKJ & 4 & 5 & 4 & 13 & 86.6 & SANGAT BAIK \\
\hline 25. & UHT & 5 & 4 & 5 & 14 & 93.3 & SANGAT BAIK \\
\hline 26. & VA & 4 & 4 & 5 & 13 & 86.6 & SANGAT BAIK \\
\hline 27. & YKGG & 5 & 4 & 5 & 14 & 93.3 & SANGAT BAIK \\
\hline 28. & YBP & 4 & 5 & 5 & 14 & 93.3 & SANGAT BAIK \\
\hline \multicolumn{2}{|c|}{ Rata-rata/Kriteria } & & & & & 90.2 & SANGAT BAIK \\
\hline
\end{tabular}

Berdasarkan tabel 3 dan 4 di atas, dapat diketahui bahwa hasil pengamatan pada siklus I di peroleh data $70.23 \%$ siswa telah berkontribusi dalam kegiatan kerja tim, dan pada siklus II juga semakin meningkat menjadi $90.23 \%$ siswa.

\section{Pembahasan}

Guna meningkatkan keterampilan kerja tim siswa, peneliti menggunakan model Problem Based Learning berbantuan Multimedia sehingga menjadi lebih optimal. Pelaksanannya yaitu dalam proses pembelajaan dengan cara melakukan perencanaan terlebih dahulu yaitu memasukkan langkah-langkah model Problem Based Learning di Rencana Pelaksanaan Pembelajaran (RPP) dengan bantuan multimedia (video pembelajaran), selanjutnya peneliti melakukan pengamatan terhadap keterampilan kerja tim siswa dalam kegiatan pemecahan masalah pada proses pembelajaran berlangsung. 


\section{ELSE (Elementary School Education Journal) \\ Volume 3 Nomor 2 Agustus 2019 \\ P-ISSN: 2581-1800 E-ISSN: 2597-4122 \\ Email: else@um-surabaya.ac.id}

Kerjasama adalah kepedulian seseorang atau pihak lain yang terlihat pada suatu kegiatan yang memberi keuntungan kepada semua pihak melalui prinsip saling percaya satu sama lain, saling menghargai, dan ada norma yang mengaturnya. (Zainudin (2013:1). Kerja sama tim dapat diartikan sebagai bentuk kerja sama dalam sebuah kelompok yang melibatkan setiap anggota tim untuk saling memberikan kontribusi sebelum mengambil sebuah keputusan atau dalam pemecahan masalah.

Indikator kerja sama menurut West (2002) dijelaskan bahawa sebagai alat ukurnya yaitu: 1) Memiliki Tanggung jawab bersama dalam menyelesaikan pekerjaan 2) Berkontribusi 3) Mengerahkan kemampuan dengan maksimal. Dalam penelitian ini. Ketiga indikator inilah yang digunakan untuk mengukur keterampilan kerja tim siswa kelas V SDN 64 Muara Bulian. Implementasi model PBL berbatuan multimedia dilakukan dalam kegiatan pemecahan masalah pada pembelajaran IPA.Pemecahan masalah dapat diartikan proses mengambil jalan keluar/ solusi dari keadaan sulit dan upaya menggapai tujuaan melalui proses atau pencapaian melalui proses pemikiran. (Hudojo, 1979).

Pada pelaksanaan kegiatan penelitian, peserta didik telah melakukan kerjasama dalam kelompok/tim. Hal ini dibuktikan dari hasil siklus 1 skor penilaian keterampilan kerja tim siswa dalam kategori baik dengan rata-rata $70.23 \%$. pada siklus II dengan hasil 90.23\% dengan kategori sangat baik. Dengan demikian, melalui bantuan multimedia, ternyata dapat mengoptimalkan model pembelajaran berbasis masalah dalam meningkatkan keterampilan kerja tim siswa di kelas V sekolah dasar.

\section{KESIMPULAN DAN SARAN}

Berdasarkan hasil penelitian, maka dapat disimpulkan sesuai dengan tujuan penelitian yaitu bentuk rencana pelaksanaan pembelajaran disusun bersama tim peneliti dan guru kelas yang mengikuti standar pada kurikulum 2013, penerapan model problem based learning berbatuan multimedia dalam meningkatkan keterampilan kerja tim, terlihat dalam kegiatan pemecahan masalah di dalam kelompok/tim pada proses pembelajaran IPA di kelas V SDN 64/I Muara Bulian. Setiap tim diberikan sebuah permasalahan melalui video pembelajaran dan mendiskusikannya bersama anggota. Selanjutnya tim mempresentasikan hasil dari diskusi /kerja tim yang telah dilakukan. Hasil pengamatan pada siklus I di peroleh data 64,28\% siswa telah berkontribusi dalam kegiatan kerja tim, dan pada siklus II juga semakin meningkat menjadi 96,42\% siswa. 


\section{ELSE (Elementary School Education Journal) \\ Volume 3 Nomor 2 Agustus 2019 \\ P-ISSN: 2581-1800 E-ISSN: 2597-4122 \\ Email: else@um-surabaya.ac.id}

Berdasarkan hasil penelitian, maka dapat dikemukakan implikasi sebagai berikut.

Model Problem Based Learning dengan dibantu multimedia seperti video pembelajaran telah berkontribusi mendukung minat belajar siswa sehingga siswa terampil dalam kerja tim/kelompok. Di dalam tim siswa melakukan kegiatan pemecahan masalah melalui video yang ditayangkan. Video pembelajaran sebagai bagian dari multimedia, mendukung kegiatan literasi teknologi sebagai tantangan pada pendidikan abad 21. Penggunaan video pembelajaran menjadikan penggunaaan model Problem Based Learning lebih optimal dan menarik perhatian siswa.

\section{DAFTAR PUSTAKA}

Afiani, KDA \& Putra, DA. 2017. Peningkatan Kemampuan Berpikir Kreatif Pada Siswa Kelas III SD Melalui Pembelajaran Berbasis Pengajuan Masalah. ELSE (Elementary School Education Journal).Volume 1 Nomor 1 Agustus 2017 P-ISSN: 2581-1800 E-ISSN: 2597-4122 hal. 38-47.

Aries dan Haryono. 2012. Penelitian Tindakan Kelas Teori dan Aplikasinya. Malang: Aditya Media Pubblishing.

Arikunto, Suharsimi. 2008. Penelitian Tindakan Kelas. Jakarta: PT Bumi Aksara.

Chotimah, N.H. 2014. Pengaruh Model Pembelajaran Generatif (MPG) Terhadap Kemampuan Pemecahan Masalah dan Disposisi Matematis Siswa di Kelas X pada SMA Negeri 8 Palembang. Skripsi.Universitas PGRI Palembang.

Hudoyo, H. 2005. Pengembangan Kurikulum Matematika \& Pelaksanaanya di Depan Kelas. Surabaya: Usaha Nasional.

Kurniawan, A.R., Kardi, S., \& Tjandrakirana. 2016. Pengembangan Perangkat Pembelajaran IPA Berbasis Pendekatan Penemuan Terbimbing Untuk Melatihkan Keterampilan Proses Siswa Sekolah Dasar. Jurnal Review Pendidikan Dasar: Jurnal Kajian Pendidikan Dan Hasil Penelitian, 2(2), 175-183.

Kuswanto, J., \& Walusfa, Y. 2017. Pengembangan Multimedia Pembelajaran pada Mata Pelajaran Teknologi Informasi dan Komunikasi Kelas VIII. Innovative Journal of Curriculum and Educational Technology, 6(2), 1-7. Retrieved from https://journal.unnes.ac.id/sju/index.php/ujet/article/view/19335.

Lestari, Yuni. 2016. Upaya Meningkatkan Kemampuan Memecahkan Masalah dan Hasil Belajar Siswa Melalui Penerapan Model Problem Based Learning Pada Mata Pelajaran IPS. Skripsi (S1) thesis, FKIP UNPAS.

Purwanto. 2011. Evaluasi Hasil Belajar. Yogyakarta : Pustaka Pelajar. 
Sanjaya, Wina. 2008. Strategi Pembelajaran Berorientasi Standar Proses Pendidikan. Jakarta: Kencana Prenada Media Group.

Susilana, Rudi dan Cepi Riyana. 2007. Media Pembelajaran. CV Wacana Prima. Bandung.

Warsita, Bambang, 2008. Teknologi Pembelajaran Landasan dan Aplikasinya. Jakarta: Rineka Cipta. 